\title{
Review of Pharmacological Properties, Phytochemistry and Medicinal Uses of Baccharoides adoensis
}

\author{
Alfred Maroyi
}

Department of Botany, University of Fort Hare, Private Bag X1314, Alice 5700, South Africa

\begin{abstract}
Baccharoides adoensis is a shrub widely used as traditional medicine throughout its distributional range in tropical Africa. This study is aimed at providing a critical review of the pharmacological properties, phytochemistry, and medicinal uses of $B$. adoensis. Documented information on the pharmacological properties, phytochemistry, and medicinal uses of $B$. adoensis was collected from several online sources which included Scopus, Google Scholar, PubMed and Science Direct. Additional information on the pharmacological properties, phytochemistry, and medicinal uses of $B$. adoensis was gathered from pre-electronic sources such as book chapters, books, journal articles, and scientific publications sourced from the university library. The articles published between 1962 and 2020 were used in this study. This study showed that the roots, flowers, stems, and leaves of $B$ adoensis are widely used as ethnoveterinary medicine and traditional medicines for backbone pain, reproductive problems, kidney diseases, fever and febrile complaints, wounds, ulcers, sexually transmitted infections, skin complaints, malaria, gastro-intestinal problems and respiratory problems. Phytochemical compounds identified from the species include alkaloids, carbohydrates, chondrillasterol, flavonoids, free sugars, glaucolides, glycosides, phenols, proanthocyanidin, saponins, steroids, tannins and terpenoids. Pharmacological research revealed that $B$. adoensis extracts and compounds isolated from the species have antimicrobial, antimycobacterial, anti-inflammatory, antioxidant, antiplasmodial, anti-pyretic, antitrypanosomal, antileishmanial, anti-ulcer and gastroprotective, immunomodulating, inhibition of Helicobacter pylori adhesion, larvicidal, cytotoxicity and toxicity activities. Baccharoides adoensis should be subjected to detailed phytochemical, pharmacological, and toxicological evaluations aimed at correlating its medicinal uses with its phytochemistry and pharmacological activities.
\end{abstract}

Keywords: Asteraceae, Baccharoides adoensis, Compositae, ethnopharmacology, herbal medicine, indigenous pharmacopeia, Vernonia adoensis.

\section{INTRODUCTION}

Baccharoides adoensis (Sch. Bip. ex Walp.) H. Rob. is a woody shrub belonging to the Asteraceae or Compositae family. This species was originally treated under the genus Vernonia Schreb. [1], a genus that is now known to be restricted to North America [1]. The genus name Baccharoides was first proposed by Moench in 1793 and remained unused until it was resurrected by Robinson in 1990 [1,2]. Synonyms associated with the name $B$. adoensis include Ascaricida adoensis Steetz, A. richardii Steetz, Cacalia adoensis Kuntze, C. grantii Kuntze, C. tigrensis Kuntze, Candidea grantii Stapf, Stengelia adoensis Sch. Bip., Vernonia adoensis Sch. Bip. ex Walp., V. goetzei Muschl., V. grantii Oliv., V. integra S. Moore, V. kotschyana Sch. Bip. ex Walp., V. latisquama Mattf., V. macrocephala A. Rich., V. polymorpha Vatke and $V$. tigrensis Oliv. \& Hiern [3]. Two infraspecific taxa are recognized and these are $B$. adoensis var. kotschyana (Sch. Bip. ex Walp.) Isawumi, El-Ghazaly \& B. Nord. and $B$. adoensis var. mossambiquensis (Steetz) Isawumi, El-Ghazaly \& B. Nord. [4] Baccharoides

*Address correspondence to this author at the Department of Botany, University of Fort Hare, Private Bag X1314, Alice 5700, South Africa; Tel: 0027406022322; E-mail: amaroyi@ufh.ac.za adoensis is a woody shrub that can grow up to 3 metres in height [5]. The stems of the species are annual, with smooth brownish bark, and multi-stemmed growing from a woody rootstock. The leaves are alternate, ovate to elliptic in shape, with acute apex and serrate margins. The leaves of $B$. adoensis are silvery dark and dull green above and paler green below, both surfaces are rather rough, harsh or sandpapery. The flowers are white in colour forming dense heads, terminal, with open or tight clusters of large round flower heads surrounded by large leaf bracts. The fruit is a tiny dry nutlet achene with white hairs at one end. Baccharoides adoensis has been recorded in Benin, Burkina Faso, Burundi, Cameroon, Central African Republic, Chad, the Democratic Republic of Congo (DRC), Eritrea, Eswatini, Ethiopia, Kenya, Nigeria, Rwanda, Senegal, South Africa, South Sudan, Sudan, Tanzania, Togo, Uganda, Zambia and Zimbabwe [1,37]. It has been recorded in disturbed bushland, grassland, mixed woodland, savanna, montane forest, along forest edges, often along rivers or drainage lines at altitudes ranging from $550 \mathrm{~m}$ to $2150 \mathrm{~m}$ above sea level $[4,6]$.

Baccharoides adoensis is an important traditional medicine in South Africa as the species is listed in the monograph of medicinal plants of the country [8]. The 
Table 1: Medicinal Uses of Baccharoides adoensis

\begin{tabular}{|c|c|c|c|}
\hline Medicinal use & Parts used & Country & References \\
\hline Arthritis & Leaves & Nigeria & [16-19] \\
\hline Diabetes & Leaves & Eswatini & [23] \\
\hline Ear infections & Leaves & Uganda & {$[15,24,25]$} \\
\hline Evil eye & $\begin{array}{l}\text { Roots mixed with those of } \\
\text { Capparis tomentosa Lam., } \\
\text { Carissa spinarum L., } \\
\text { Croton macrostachyus } \\
\text { Hochst. ex Delile and } \\
\text { Pterolobium stellatum } \\
\text { (Forssk.) Brenan }\end{array}$ & Ethiopia & [13] \\
\hline Eye problems & Leaves and roots & Kenya & [24] \\
\hline Fever and febrile complaints & Leaves & South Africa and Tanzania & {$[18,21,25,27-30]$} \\
\hline $\begin{array}{l}\text { Gastro-intestinal problems } \\
\text { (appetizer, diarrhoea, digestive } \\
\text { problems, indigestion and } \\
\text { stomach problems) }\end{array}$ & Leaves, roots and stems & $\begin{array}{c}\text { Eswatini, Ethiopia, Mali, } \\
\text { Nigeria, South Africa and } \\
\text { Tanzania }\end{array}$ & $\begin{array}{c}{[10,12,13,16-19,21,23,32,33,35,37,39-} \\
45]\end{array}$ \\
\hline Gingivitis & Leaves & Nigeria & [16-19] \\
\hline Heart diseases & Leaves & Kenya & {$[29,30,46-48]$} \\
\hline Herpes zoster & Roots & Kenya & [49] \\
\hline Hypertension & Roots & Ethiopia & [13] \\
\hline Inflammation & Roots & Nigeria & [50] \\
\hline Kidney diseases & Leaves and roots & Ethiopia and Kenya & {$[29,30,46-48,51]$} \\
\hline $\begin{array}{l}\text { Reproductive problems (infertility } \\
\text { and sexual dysfunction) }\end{array}$ & Roots & Ethiopia and Zimbabwe & {$[22,51,52]$} \\
\hline $\begin{array}{c}\text { Respiratory problems (chest } \\
\text { complaints, cough, flu and } \\
\text { tuberculosis) }\end{array}$ & Leaves and roots & $\begin{array}{l}\text { Eswatini, Ethiopia, Nigeria, } \\
\text { South Africa, Tanzania and } \\
\text { Uganda }\end{array}$ & {$[15-21,23,25,28-33,41,45,57-64]$} \\
\hline $\begin{array}{l}\text { Sexually transmitted infections } \\
\text { (genital ulcers, gonorrhoea and } \\
\text { human immunodeficiency } \\
\text { virus/acquired immunodeficiency } \\
\text { syndrome (HIV/AIDS) }\end{array}$ & Leaves and roots & $\begin{array}{c}\text { Kenya, Nigeria, Tanzania and } \\
\text { Uganda }\end{array}$ & {$[16-19,25,29,30,41,45-49,57,65-67]$} \\
\hline $\begin{array}{l}\text { Skin complaints (blotches, head } \\
\text { lice, rash and scabies) }\end{array}$ & Flowers, leaves and roots & $\begin{array}{l}\text { Eswatini, Nigeria, South } \\
\text { Africa, Tanzania, Uganda and } \\
\text { Zimbabwe }\end{array}$ & {$[15,18,20,21,23-25,31,41,61,68]$} \\
\hline Snake and scorpion bites & Leaves and roots & Ethiopia & {$[13,18,22,69,70]$} \\
\hline Ulcers & Roots & Cameroon and Mali & {$[10-12,18,19,32-40,43,71]$} \\
\hline Urinary problems & Leaves and stems & South Africa & {$[20,21]$} \\
\hline Worms & Roots & Ethiopia & [13] \\
\hline $\begin{array}{c}\text { Wounds including circumcision } \\
\text { wounds }\end{array}$ & Leaves and roots & Ethiopia and Mali & $\begin{array}{c}{[10,12,18,19,22,25,35,39,40,43,45,69,7} \\
2]\end{array}$ \\
\hline $\begin{array}{l}\text { Ethnoveterinary medicine (tick- } \\
\text { bite sores and worms) }\end{array}$ & Leaves & Kenya and Uganda & {$[7,18,41,73]$} \\
\hline
\end{tabular}


leaves, roots and stems of $B$. adoensis are sold as herbal medicines in Mali and South Africa $[9,10]$. The powdered roots of $B$. adoensis are commercially available in Malian pharmacies and other outlets selling pharmaceutical drugs and health products using the trade name gastrosedal. The pharmaceutical product gastrosedal is on the national list of essential drugs in Mali for treatment of gastritis and gastric ulcers [9]. As the roots of $B$. adoensis are used to produce gastrosedal, the wild populations of the species have decreased considerably over the years and the species is now cultivated in several areas and home gardens in Mali $[11,12]$. It is, therefore, within this background that the current study was undertaken aimed at documenting the pharmacological properties, phytochemistry, and medicinal uses of $B$. adoensis.

\section{Medicinal Uses}

The roots, flowers, stems and leaves of $B$. adoensis are widely used as ethnoveterinary medicine and traditional medicines for backbone pain, reproductive problems, kidney diseases, fever and febrile complaints, wounds, ulcers, sexually transmitted infections, skin complaints, malaria, gastro-intestinal problems and respiratory problems (Table 1; Figure 1). In Ethiopia, roots of B adoensis are mixed with those of Capparis tomentosa Lam., Carissa spinarum L., Croton macrostachyus Hochst. ex Delile and Pterolobium stellatum (Forssk.) Brenan and used as traditional medicine for evil eye [13]. In Uganda, the leaves of $B$. adoensis are mixed with those of Aloe vera (L.) Burm. f. as herbal medicine for malaria $[14,15]$.

\section{Phytochemistry}

Bohlmann et al. [74] identified flavonoids and glaucolides, 14-hydroxy-8-desacyl-2,3dehydrovernonataloide-8-O-methacrylate and 14hydroxy-8-desacyl-2,3-dehydrovernonataloide-8-O-[2methyl butyrate] from the aerial parts of $B$. adoensis. Sanogo et al. [33] isolated stigmastane-type steroidal glycosides, vernoniosides D1, D2, D3, F1 and F2, as well as androst-8-en glycoside from the root of $B$. adoensis. Nergard et al. [42] isolated two polysaccharides, a pectin and a pectic arabinogalactan from roots of $B$. adoensis. Austarheim et al. [10] and Inngjerdingen et al. [11] identified arabinose, rhamnose, galactose, galacturonic acid, glucuronic acid, 4-O-methyl glucuronic acid, glucose, mannose, fructose, and phenols from the roots of $B$. adoensis. Mozirandi et al. [30] identified the compound chondrillasterol from the leaves of $B$. adoensis. Several other researchers identified alkaloids, carbohydrates, flavonoids, free sugars, glycosides, phenols, proanthocyanidin, saponins, steroids, tannins and terpenoids from flowers, leaves, roots and root bark of B. Adoensis $[12,17,28,48,55,64,67,75]$.

\section{Pharmacological Properties}

The following biological activities have been reported from the flower, leaf, root and stem bark extracts of $B$. adoensis and the compounds isolated from the species: antimicrobial, antimycobacterial, antiinflammatory, antioxidant, antiplasmodial, anti-pyretic, antitrypanosomal, antileishmanial, anti-ulcer antiulcer

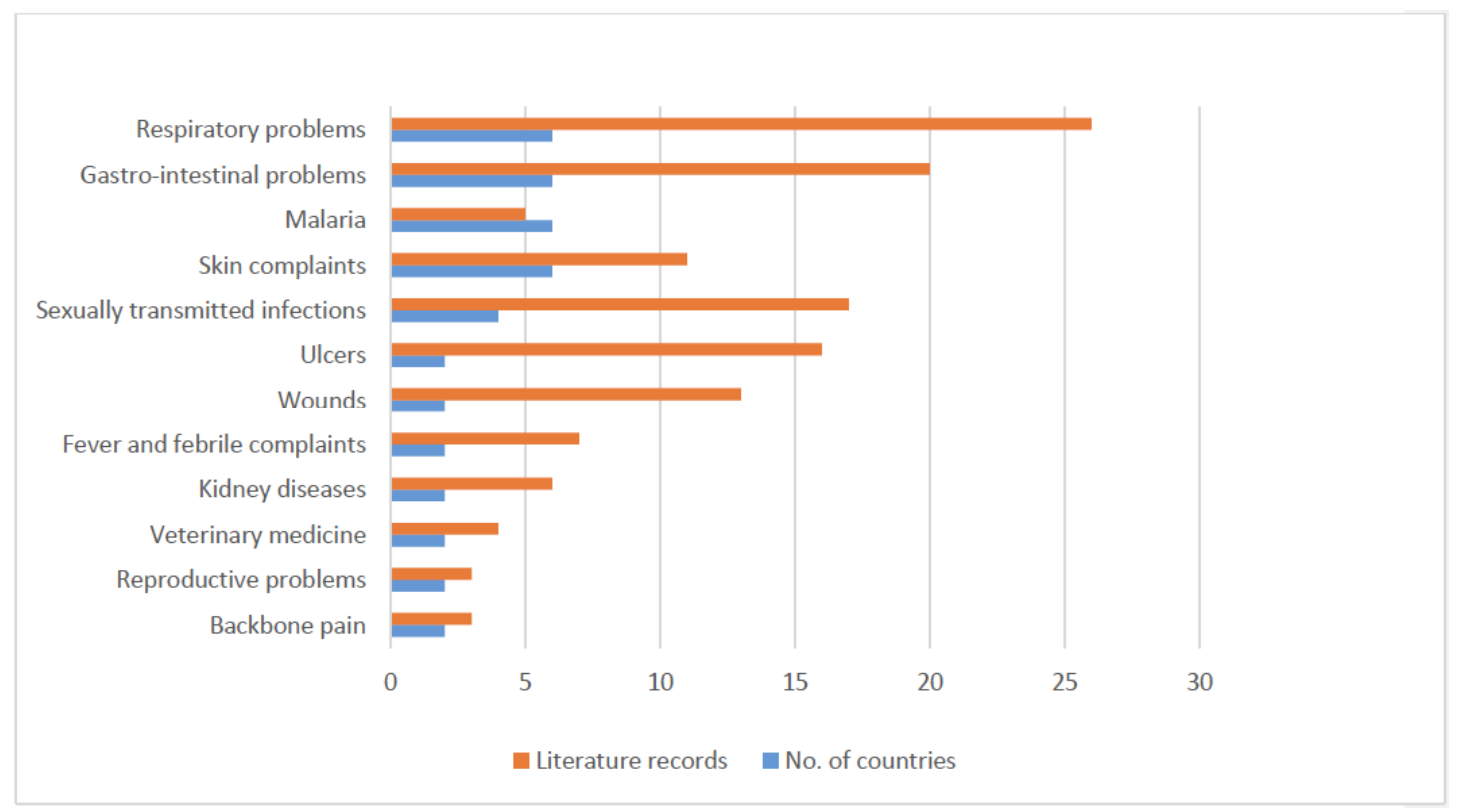

Figure 1: Medicinal applications of Baccharoides adoensis derived from literature records. 
and gastroprotective, immunomodulating, inhibition of Helicobacter pylori adhesion, larvicidal, cytotoxicity and toxicity activities.

\section{Antimicrobial Activities}

Preliminary evaluations of antibacterial activities of $B$. adoensis leaf extracts revealed activities against both Gram-negative and Gram-positive bacteria [42]. Kisangau et al. [58] evaluated the antibacterial activities of petroleum ether, dichloromethane, and water extracts of $B$. adoensis leaves against Staphylococcus aureus, Bacillus subtilis, Escherichia coli and Pseudomonas aeruginosa using the agar well and disc diffusion assays with ampicillin $(0.5 \mathrm{mg} / \mathrm{ml})$ and gentamicin $(0.5 \mathrm{mg} / \mathrm{ml})$ as positive controls. The petroleum ether and dichloromethane extracts exhibited activities against Bacillus subtilis and Escherichia coli with zone of inhibition of $4.0 \mathrm{~mm}$ and $6.5 \mathrm{~mm}$, respectively, while water extracts exhibited activities against Staphylococcus aureus, Bacillus subtilis and Escherichia coli with a zone of inhibition ranging from $10.0 \mathrm{~mm}$ to $46.0 \mathrm{~mm}$ [58]. Chitemerere and Mukanganyama [61] evaluated the antibacterial activities of ethanolic extracts of $B$. adoensis leaves against Escherichia coli, Bacillus cereus, Bacillus subtilis, Staphylococcus aureus and Pseudomonas aeruginosa using the agar diffusion assay and microplate method with ampicillin as a positive control. The extract exhibited activities with the zone of inhibition ranging from $15.0 \mathrm{~mm}$ to $25.0 \mathrm{~mm}$, which was comparable to $21.0 \mathrm{~mm}$ to $45.0 \mathrm{~mm}$ exhibited by the positive control. The minimum inhibitory concentration (MIC) and minimum bactericidal concentration (MBC) values ranged from $94.0 \mu \mathrm{g} / \mathrm{ml}$ to $188.0 \mu \mathrm{g} / \mathrm{ml}$, and $500.0 \mu \mathrm{g} / \mathrm{ml}$ to $1000.0 \mu \mathrm{g} / \mathrm{ml}$, respectively [61]. Ibrahim and Ogaji [17] evaluated the antimicrobial activities of crude flavonoids isolated from $B$. adoensis leaves against Staphylococcus aureus, Escherichia coli, Aspergillus niger and Candida albicans using agar well diffusion and dilution methods with ofloxacin $(20 \mu \mathrm{g} / \mathrm{ml})$ and fluconazole $(20 \mu \mathrm{g} / \mathrm{ml})$ as positive controls. The flavonoids exhibited activities against the tested pathogens with the MIC values ranging from 12.5 $\mathrm{mg} / \mathrm{ml}$ to $25.0 \mathrm{mg} / \mathrm{ml}$ [17]. Mutuku et al. [46] evaluated the antibacterial activities of the methanol : water (9:1) extract of $B$. adoensis leaves against Salmonella typhi, Klebsiella spp., Klebsiella aerogenes, Bacillus cereus, Streptococcus pyogenes, Escherichia coli and Proteus vulgaris using the agar well diffusion method with augmentin as a positive control. The extract exhibited activities against Klebsiella spp., Bacillus cereus, Streptococcus pyogenes and Escherichia coli with a zone of inhibition ranging from $11.7 \mathrm{~mm}$ to $20.2 \mathrm{~mm}$ in comparison to the zone of inhibition of $28.4 \mathrm{~mm}$ to 37.0 $\mathrm{mm}$ exhibited by the positive control [46]. Swamy et al. [47] evaluated the antibacterial activities of the methanol : water $(9: 1)$ extract of $B$. adoensis roots against Salmonella typi, Klebsiella spp., Klebsiella aerogenes, Bacillus cereus, Streptococcus pyogenes, Escherichia coli and Proteus vulgaris using the agar well diffusion method with augmentin as a positive control. The extract exhibited activities against Bacillus cereus, Streptococcus pyogenes and Proteus vulgaris with a zone of inhibition ranging from $10.0 \mathrm{~mm}$ to 15.7 $\mathrm{mm}$ in comparison to the zone of inhibition of $28.5 \mathrm{~mm}$ to $38.3 \mathrm{~mm}$ exhibited by the positive control [47]. Mabhiza et al. [28] evaluated the antibacterial activities of alkaloids isolated from $B$. adoensis leaves against Staphylococcus aureus and Pseudomonas aeruginosa using the broth microdilution assay with ampicillin as a positive control. The compound exhibited activities with the MIC values of $0.2 \mathrm{mg} / \mathrm{mL}$ and $0.4 \mathrm{mg} / \mathrm{mL}$ against Staphylococcus aureus and Pseudomonas aeruginosa, respectively, which were higher than the MIC value of $0.008 \mathrm{mg} / \mathrm{mL}$ exhibited by the positive control [28]. Muhindi et al. [75] evaluated the antibacterial activities of acetone and methanol extracts of $B$. adoensis stem bark against Klebsiella aerogenes, Enterococcus faecalis, Staphylococcus epidermidis and Streptococcus pyogenes using the disc diffusion method with penicillin as a positive control. The extracts exhibited activities against the tested pathogens with the exception of Streptococcus pyogenes, which was found to be resistant against the acetone extract. The zone of inhibition ranged from 9.0 $\mathrm{mm}$ to $16.0 \mathrm{~mm}$ against the zone of inhibition of 19.3 $\mathrm{mm}$ to $43.3 \mathrm{~mm}$ exhibited by the positive control [75]. Mozirandi and Mukanganyama [29] evaluated antibacterial activities of water, acetone, hexane, ethyl acetate, ethanol, methanol, and dichloromethane extracts of $B$. adoensis leaves against Staphylococcus aureus and Pseudomonas aeruginosa using the broth microdilution method and time kill assays. All the extracts had an inhibitory effect on the growth of tested pathogens with acetone extract exhibiting the best activities with the MIC value of $1.6 \mu \mathrm{g} / \mathrm{ml}$ and the MBC value of $6.3 \mu \mathrm{g} / \mathrm{ml}$ against Pseudomonas aeruginosa. In the time kill assay, the MBC concentration revealed bactericidal activities after 30 minutes of incubation with Pseudomonas aeruginosa [29]. Mozirandi et al. [30] evaluated the antibacterial activities of the compound chondrillasterol isolated from the leaves of B. adoensis against Staphylococcus aureus, Klebsiella pneumoniae and Pseudomonas aeruginosa using the broth microdilution assay with ciprofloxacin as a 
positive control. The compound exhibited $25 \%, 38 \%$ and $65 \%$ inhibition of growth on Staphylococcus aureus, Klebsiella pneumoniae and Pseudomonas aeruginosa, respectively [30].

\section{Antimycobacterial Activities}

Chimponda and Mukanganyama [60] evaluated the antimycobacterial activities of ethanol extracts of $B$. adoensis flowers, leaves and roots against Mycobacterium aurum and Corynebacterium glutamicum using the agar disk diffusion method with rifampicin as a positive control. At $500 \mathrm{mg} / \mathrm{disk}$, the extracts exhibited activities against the tested pathogens with a zone of inhibition of $28.0 \mathrm{~mm}$, MIC value of $31.0 \mu \mathrm{g} / \mathrm{disk}$ and a MBC value of $250.0 \mu \mathrm{g} / \mathrm{disk}$ [60]. Mautsa and Mukanganyama [64] evaluated the antimycobacterial activities of ethyl acetate and hexane extracts as well as the compounds alkaloid and terpenoid isolated from $B$. adoensis flowers and leaves against Mycobacterium tuberculosis using the microbroth dilution method. The ethyl acetate extract was the most active with the MIC and the MBC values of $63.0 \mu \mathrm{g} / \mathrm{ml}$ and $250.0 \mu \mathrm{g} / \mathrm{ml}$, respectively [64].

\section{Anti-Inflammatory Activities}

Ibrahim et al. [16] evaluated the anti-inflammatory activities of ethanol extracts of $B$. adoensis leaves using the carrageenan induced hind paw oedema in rats. The extract exhibited $45.5 \%$ carrageenan induced hind paw oedema in rats at $50 \mathrm{mg} / \mathrm{kg}$ i.p. [16].

\section{Antioxidant Activities}

Stangeland et al. [54] evaluated the antioxidant activities of acetone, dichloromethane, methanol, chlorine water, and methanol extracts of $B$. adoensis leaves using 2,2-diphenyl-1-picrylhydrazyl (DPPH) free radical scavenging and ferric reducing ability of plasma (FRAP) assays. The extracts exhibited activities with half maximal inhibitory concentration $\left(\mathrm{IC}_{50}\right)$ values in DPPH ranging from $33.3 \mu \mathrm{g} / \mathrm{ml}$ to $>167.0 \mu \mathrm{g} / \mathrm{ml}$ while FRAP values ranged from $193.2 \mu \mathrm{mol} / \mathrm{g}$ to 2562.3 $\mu \mathrm{mol} / \mathrm{g}$ [54]. Nethengwe et al. [55] evaluated the antioxidant activities of methanol extracts of $B$. adoensis leaves and roots using DPPH, 2,2'-azinobis(3-ethylbenzothiazoline-6-sulphonic acid (ABTS) free radical scavenging, ferrous ion chelating activity assay, hydroxyl radicals ( $\mathrm{HO}$ ), nitric oxide (NO) and superoxide radicals (SO) scavenging ability, and the total antioxidant capacity with ascorbic acid, butylated hydroxy toluene (BHT), citric acid and ethylenediaminetetraacetic acid (EDTA) as positive controls. The extracts exhibited activities with the $\mathrm{IC}_{50}$ values ranging from $0.7 \mu \mathrm{g} / \mathrm{ml}$ to $5.2 \mu \mathrm{g} / \mathrm{ml}$ [55]. Vasincu et al. [12] evaluated the antioxidant activities of chloroform, ethyl acetate and ethanol extracts of $B$. adoensis roots using ABTS, SO, HO, NO, lipid peroxidation inhibition, ferrous ion chelating and cellbased antioxidant assays. The extracts exhibited varying degrees of activities with half maximal effective concentration $\left(E_{50}\right)$ values ranging from $0.2 \mu \mathrm{g} / \mathrm{ml}$ to $370.4 \mu \mathrm{g} / \mathrm{ml} \mathrm{[12]} \mathrm{Mautsa} \mathrm{and} \mathrm{Mukanganyama} \mathrm{[64]}$ evaluated the antioxidant activities of ethyl acetate extract of $B$. adoensis leaves using the DPPH free radical scavenging assay with ascorbic acid as a positive control. The extract exhibited weak activities with $\mathrm{IC}_{50}$ value of $114.8 \mu \mathrm{g} / \mathrm{ml}$, which was much higher than the $I_{50}$ value of $7.4 \mu \mathrm{g} / \mathrm{ml}$ exhibited by the positive control [64].

\section{Antiplasmodial Activities}

Stangeland et al. [54] evaluated the antiplasmodial activities of acetone, dichloromethane, methanol, chlorine water and methanol extracts of $B$. adoensis leaves using an enzyme-linked immunosorbent assay (ELISA) on Plasmodium falciparum chloroquine sensitive strain MRA-285 line with chloroquine as a positive control. All extracts exhibited activities with the $\mathrm{IC}_{50}$ values ranging from $2.1 \mu \mathrm{g} / \mathrm{ml}$ to $2.8 \mu \mathrm{g} / \mathrm{ml}$ in comparison to $8.0 \mu \mathrm{g} / \mathrm{ml}$ exhibited by the positive control [54]. Nethengwe et al. [55] evaluated the antiplasmodial activities of dichloromethane and methanol extracts of $B$. adoensis leaves and roots against chloroquine sensitive strain of Plasmodium falciparum using the parasite lactate dehydrogenase assay. The methanol extract of the leaves exhibited the best activities with the $\mathrm{IC}_{50}$ value of $2.9 \mu \mathrm{g} / \mathrm{ml}$ [55]. Zemicheal and Mekonnen [45] evaluated the antiplasmodial activities of the crude aqueous, methanol and chloroform extracts of the leaves of $B$. adoensis in Plasmodium berghei infected Swiss albino mice using Peters' 4-day suppressive test. The extracts demonstrated significant suppression of parasitaemia in the treated mice with inhibition ranging from $54.3 \%$ to $83.4 \%$ at an oral dose of $600 \mathrm{mg} / \mathrm{kg}$ body weight [45]. Obbo et al. [25] evaluated the antiplasmodial activities of petroleum ether, dichloromethane, methanol and water extracts of $B$. adoensis leaves against Plasmodium falciparum using a modified $\mathrm{G}-{ }^{3} \mathrm{H}-$ hypoxanthine incorporation assay in the chloroquine and pyrimethamine-resistant $\mathrm{K} 1$ strains with chloroquine and artemisinin as positive controls. The extracts exhibited activities with the $\mathrm{IC}_{50}$ values ranging from $1.0 \mu \mathrm{g} / \mathrm{ml}$ to $>5.0 \mu \mathrm{g} / \mathrm{ml}$ [25]. 


\section{Anti-Pyretic Activities}

Nethengwe et al. [55] evaluated anti-pyretic activities of water and methanol extracts of $B$. adoensis leaves and roots using the brewer's yeast induced pyrexia model in Sprague-Dawley rats. The extracts exhibited the potential to reduce pyrexia in the induced rats exhibiting time and concentration-dependent activities with the extracts showing activities as from 30 minutes even at the lowest concentration of $100 \mathrm{mg} / \mathrm{kg}$ [55].

\section{Antitrypanosomal Activities}

Obbo et al. [25] evaluated the antitrypanosomal activities of petroleum ether, dichloromethane, methanol, and water extracts of B. adoensis leaves against Trypanosoma brucei rhodesiense and Trypanosoma cruzi using the Alamar Blue assay and assay for $\beta$-galactosidase, respectively, with melarsoprol as a positive control. The extracts exhibited activities against both pathogens with the $\mathrm{IC}_{50}$ values ranging from $1.6 \mu \mathrm{g} / \mathrm{ml}$ to $>90.0 \mu \mathrm{g} / \mathrm{ml}$ in comparison to $0.007 \mu \mathrm{g} / \mathrm{ml}$ exhibited by the positive control [25].

\section{Antileishmanial Activities}

Obbo et al. [25] evaluated antileishmanial activities of petroleum ether, dichloromethane, methanol and water extracts of $B$. adoensis leaves against both extracellular promastigotes and intracellular amastigotes of Leishmania donovani with beznidazole as a positive control. The extracts exhibited activities with the $\mathrm{IC}_{50}$ values ranging from $>3.3 \mu \mathrm{g} / \mathrm{ml}$ to $>30.0$ $\mu \mathrm{g} / \mathrm{ml}$ in comparison to $0.3 \mu \mathrm{g} / \mathrm{ml}$ exhibited by the positive control [25].

\section{Anti-Ulcer Antiulcer and Gastroprotective Activities}

Germanò et al. [32] evaluated the gastroprotective activities of aqueous extract of $B$. adoensis roots in ethanol-induced gastro-duodenal ulcer in male Swiss albino Sprague-Dawley rats. The extract caused a reduction in the number and severity of ethanolinduced ulcers and did not produce any changes in volume, $\mathrm{pH}$ and total acid output in pyloric-ligated rats [32]. Austarheim et al. [10] evaluated the anti-ulcer activities of inulin-rich fractions from $B$. adoensis roots by gastric lesion models in Swiss albino mice. The extract significantly inhibited the formation of gastric lesions in mice at $100 \mathrm{mg} / \mathrm{kg}$ [10]. Vasincu et al. [19] evaluated the antiulcer and gastroprotective activities of aqueous extract of $B$. adoensis roots on two mice models of gastric ulcer induced by indomethacin and absolute ethanol. The results of antiulcer activities showed that the extract exhibited activities with half maximal effective dose $\left(E D_{50}\right)$ value of $557.1 \mathrm{mg} / \mathrm{kg}$ body weight while gastroprotective activities exhibited an $\mathrm{ED}_{50}$ value of $439.9 \mathrm{mg} / \mathrm{kg}$ body weight [19].

\section{Immunomodulating Activities}

Nergard et al. [35,43] evaluated the immunomodulating activities of acidic polysaccharides isolated from $B$. adoensis roots. The polysaccharides showed fixation activities and induced chemotaxis of human macrophages, $\mathrm{T}$ cells and NK cells $[35,43]$.

\section{Inhibition of Helicobacter pylori Adhesion Activities}

Inngjerdingen et al. [38] evaluated the anti-adhesive activities of water extracts and polysaccharide fractions isolated from $B$. adoensis roots towards Helicobacter pylori using an in vitro flow cytometric assay on human gastric adenocarcinoma epithelial cells. The polysaccharide fractions caused approximately $30 \%$ inhibition of Helicobacter pylori adhesion to gastric adenocarcinoma epithelial cells [38].

\section{Larvicidal Activities}

Nethengwe et al. [55] evaluated the larvicidal activities of dichloromethane and methanol extracts of $B$. adoensis leaves and roots using the mosquito larvicidal assay. The dichloromethane and methanol extracts of the leaves caused $80.0 \%$ and $73.0 \%$ mortality of the fourth-instar larvae of Culex quinquefascitus [55].

\section{Cytotoxicity and Toxicity Activities}

Obbo et al. [25] evaluated cytotoxicity activities of dichloromethane extracts of $B$. adoensis leaves using the rat skeletal myoblast (L6) and murine macrophage (J774) cells. The extract exhibited activities with the $\mathrm{IC}_{50}$ values of $3.3 \mu \mathrm{g} / \mathrm{ml}$ and $10.0 \mu \mathrm{g} / \mathrm{ml}$ against $\mathrm{L} 6$ and J774 cells, respectively [25]. Vasincu et al. [40] evaluated the acute toxicity of ethyl acetate, ethanol and water extracts of $B$. adoensis roots in Swiss albino mice. The extracts were administered orally in doses of 800,1600 and $3200 \mathrm{mg} / \mathrm{kg}$ body weight, and the mice monitored daily for 14 days. The ethyl acetate demonstrated slight toxicity with median lethal dose $\left(L_{50}\right)$ value within the range of $2021.1 \pm 1484.2 \mathrm{mg} / \mathrm{kg}$ body weight while the other extracts were not found to be toxic [40]. 


\section{CONCLUSION}

The present review summarizes the medicinal uses, phytochemistry, and pharmacological properties of $B$. adoensis. Although $B$. adoensis has been the subject of phytochemical and pharmacological research, there is not yet enough data correlating the ethnomedicinal uses of the species with its phytochemical and pharmacological properties. Detailed studies on the pharmacokinetics, in vivo and clinical research involving both extracts and compounds isolated from the species are required. Therefore, future research should focus on the molecular modes or mechanisms of action, pharmacokinetics, and physiological pathways for specific extracts of the species including the identification of the bioactive compounds of the species and their associated pharmacological activities.

\section{REFERENCES}

[1] Isawumi MA, El-Ghazaly G, Nordenstam B. Pollen morphology, floral microcharacters and taxonomy of the genus Baccharoides Moench (Vernonieae: Asteraceae). Grana 1996; 35: 205-30. https://doi.org/10.1080/00173139609430008

[2] Robinson H. Six new combinations in Baccharoides Moench and Cyanthillium Blume (Vernonieae: Asteraceae). Proceed Biol Soc Washington 1990; 103: 248-53.

[3] Robinson H, Skvarla JJ, Funk VA. Vernonieae (Asteraceae) of southern Africa: A generic disposition of the species and a study of their pollen. PhytoKeys 2016; 60: 49-126. https://doi.org/10.3897/phytokeys.60.6734

[4] Germishuizen G, Meyer NL. Plants of southern Africa: An annotated checklist. Pretoria: Strelitzia 14, National Botanical Institute; 2003.

[5] Schmidt E, Lotter M, McCleland W. Trees and shrubs of Mpumalanga and Kruger National Park. Johannesburg: Jacana Media; 2017.

[6] Pope GV. Compositae. In Pope GV (Ed.), Flora Zambesiaca: Mozambique, Malawi, Zambia, Zimbabwe and Botswana vol. 6 (1). Richmond: Royal Botanic Gardens, Kew; 1992, pp. 1264.

[7] Dharani N. Field guide to common trees and shrubs of East Africa. Cape Town: Struik Nature; 2019.

[8] Van Wyk B-E, Van Oudtshoorn B, Gericke N. Medicinal plants of South Africa. Pretoria: Briza Publications; 2013.

[9] Cunningham AB. African medicinal plants: setting priorities at the interface between conservation and primary health care. Paris: People and Plants working paper 1, UNESCO; 1993.

[10] Austarheim I, et al. Inulin-rich fractions from Vernonia kotschyana roots have anti-ulcer activity. J Ethnopharmacol 2012; 144: 82-5.

https://doi.org/10.1016/j.jep.2012.08.031

[11] Inngjerdingen $\mathrm{KT}$, et al. Chemical and biological characterization of polysaccharides from wild and cultivated roots of Vernonia kotschyana. J Ethnopharmacol 2012; 139: 350-8. https://doi.org/10.1016/j.jep.2011.10.044

[12] Vasincu A, et al. Vernonia kotschyana roots: therapeutic potential via antioxidant activity. Molecules 2014; 19: 19114-36. https://doi.org/10.3390/molecules 191119114

[13] Mekuanent T, Zebene A, Solomon Z. Ethnobotanical study of medicinal plants in Chilga district, northwestern Ethiopia. $J$ Nat Remedies 2015; 15(2): 88-112. https://doi.org/10.18311/jnr/2015/476
[14] Anywar G, et al. Medicinal plants used in the treatment and prevention of malaria in Cegere subcounty, northern Uganda. Ethnobot Res Appl 2016; 14: 505-16. https://doi.org/10.17348/era.14.0.505-516

[15] Okello D, Kang Y. Exploring antimalarial herbal plants across communities in Uganda based on electronic data. EvidenceBased Compl Alt Med 2019; article ID 3057180. https://doi.org/10.1155/2019/3057180

[16] Ibrahim G, et al. Studies on acute toxicity and antiinflammatory effects of Vernonia kotschyana Sch. Bip. (Asteraceae) ethanol leaf extract. Nigerian J Pharmaceut Sci 2009; 8: 8-12.

[17] Ibrahim G, Ogaji YN. Crude flavonoids from Vernonia kotschyana possess antimicrobial activity. Nigerian J Pharmaceut Sci 2012; 11(2): 41-9.

[18] Toyang NJ, Verpoorte R. A review of the medicinal potentials of plants of the genus Vernonia (Asteraceae). J Ethnopharmacol 2013; 146: 681-723. https://doi.org/10.1016/j.jep.2013.01.040

[19] Vasincu A, et al. Effects of aqueous extract of Vernonia kotschyana Sch. Bip. ex Walp roots on experimental gastric ulcer in mice. Farmacia 2019; 67(5): 836-43. https://doi.org/10.31925/farmacia.2019.5.12

[20] Pujol J. Nature Africa: The herbalist handbook. Durban: Jean Pujol Natural Healers' Foundation; 1990.

[21] Hutchings A, et al. Zulu medicinal plants: An inventory. Pietermaritzburg: University of Natal Press; 1996.

[22] Mengesha GG. Ethnobotanical survey of medicinal plants used in treating human and livestock health problems in Mandura Woreda of Benishangul Gumuz, Ethiopia. Advancement Med Plant Res 2016; 4(1): 11-26.

[23] Long C. Swaziland's flora: Siswati names and uses. Mbambane, Swaziland: Swaziland National Trust Commission, 2005. Available from: http://www .sntc.org.sz/index.asp, accessed on 19 January 2020].

[24] Tugume $P$, et al. Ethnobotanical survey of medicinal plant species used by communities around Mabira Central Forest Reserve, Uganda. J Ethnobiol Ethnomed 2016; 12 : 5. https://doi.org/10.1186/s13002-015-0077-4

[25] Obbo CJD, et al. In vitro antiplasmodial, antitrypanosomal and antileishmanial activities of selected medicinal plants from Ugandan flora: refocusing into multi-component potentials. J Ethnopharmacol 2019; 229: 127-36. https://doi.org/10.1016/i.jep.2018.09.029

[26] Odongo $\mathrm{E}$, et al. Ethnobotanical survey of the medicinal plants used in Kakamega County, western Kenya. Appl Med Res 2018; 4(2): 22-40.

https://doi.org/10.5455/amr.20180315095706

[27] Bryant AT. Zulu medicine and medicine-men. Cape Town: C Struik; 1966.

[28] Mabhiza D, Chitemerere T, Mukanganyama S. Antibacterial properties of alkaloid extracts from Callistemon citrinus and Vernonia adoensis against Staphylococcus aureus and Pseudomonas aeruginosa. Int J Med Chem 2016; article ID 6304163. https://doi.org/10.1155/2016/6304163

[29] Mozirandi W, Mukanganyama S. Antibacterial activity and mode of action of Vernonia adoensis (Asteraceae) extracts against Staphylococcus aureus and Pseudomonas aeruginosa. J Biologically Active Prod Nat 2017; 7(5): 341-57. https://doi.org/10.1080/22311866.2017.1378922

[30] Mozirandi W, Tagwireyi D, Mukanganyama S. Evaluation of antimicrobial activity of chondrillasterol isolated from Vernonia adoensis (Asteraceae). BMC Compl Alt Med 2019; 19: 249 https://doi.org/10.1186/s12906-019-2657-7

[31] Watt JM, Breyer-Brandwijk MG. The medicinal and poisonous plants of southern and eastern Africa. London: Livingstone; 1962. 
[32] Germanò MP, et al. Antiulcer activity of Vernonia kotschyana Sch. Bip. Phytomedicine 1996; 2: 229-33. https://doi.org/10.1016/S0944-7113(96)80047-X

[33] Sanogo R, et al. Vernoniosides and an androstane glycoside from Vernonia kotschyana. Phytochemistry 1998; 47: 73-8. https://doi.org/10.1016/S0031-9422(97)00477-9

[34] Inngjerdingen $\mathrm{K}$, et al. An ethnopharmacological survey of plants used for wound healing in Dogonland, Mali, West Africa. J Ethnopharmacol 2004; 92: 233-44. https://doi.org/10.1016/j.jep.2004.02.021

[35] Nergard CS, et al. Isolation, partial characterisation and immunomodulating activities of polysaccharides from Vernonia kotschyana Sch. Bip. ex Walp. J Ethnopharmacol 2004; 91: 141-52.

https://doi.org/10.1016/j.jep.2003.12.007

[36] Focho DA, Ndam WT, Fonge BA. Medicinal plants of Aguambu-Bamumbu in the Lebialem highlands, southwest province of Cameroon. Afr J Pharm Pharmacol 2009; 3: 1-13.

[37] Willcox $\mathrm{M}$, et al. Improved traditional medicines in Mali. J Alt Compl Med 2012; 18: 212-220.

https://doi.org/10.1089/acm.2011.0640

[38] Inngjerdingen $\mathrm{KT}$, et al. Inhibition of Helicobacter pylori adhesion to human gastric adenocarcinoma epithelial cells by aqueous extracts and pectic polysaccharides from the roots of Cochlospermum tinctorium A. Rich. and Vernonia kotschyana Sch. Bip. ex Walp. Fitoterapia 2014; 95: 127-32. https://doi.org/10.1016/j.fitote.2014.03.009

[39] Harding SE, et al. An introduction to polysaccharide biotechnology. Boca Raton: CRC Press; 2017.

[40] Vasincu A, et al. Preliminary experimental research on acute toxicity of Vernonia kotschyana extracts in mice. Veterinary Drug 2018; 12(1): 57-62.

[41] Burkill HM. The useful plants of West tropical Africa. Richmond: Royal Botanic Gardens, Kew; 1985.

[42] Deeni YY, Hussain HSN. Screening of Vernonia kotchyana for antimicrobial activity and alkaloids. Int J Pharmacog 1994; 32: 388-95.

\section{https://doi.org/10.3109/13880209409083021}

[43] Nergard CS, et al. Structural and immunological studies of a pectin and a pectic arabinogalactan from Vernonia kotschyana Sch. Bip. ex Walp. (Asteraceae). Carbohydrydrate Res 2005; 340: 115-30.

https://doi.org/10.1016/j.carres.2004.10.023

[44] Giday M, et al. Medicinal plants of the Shinasha, Agew-awi and Amhara peoples in northwest Ethiopia. J Ethnopharmacol 2007; 110: 516-25. https://doi.org/10.1016/j.jep.2006.10.011

[45] Zemicheal G, Mekonnen Y. Antiplasmodial activity of Vernonia adoensis aqueous, methanol and chloroform leaf extracts against chloroquine sensitive strain of Plasmodium berghei in vivo in mice. BMC Res Notes 2018; 11: 736. https://doi.org/10.1186/s13104-018-3835-2

[46] Mutuku NC, Swamy TA, Jackie O. In vitro control of selected pathogenic microorganisms by Vernonia adoensis leaves. Int J Bioassays 2013; 2(8): 1113-7.

[47] Swamy TA, Jackie O, Mutuku NC. In vitro control of selected pathogenic organisms by Vernonia adoensis roots. Int $\mathrm{J}$ Pharm Life Sci 2013; 4(8): 2855-9.

[48] Swamy AT, Mutuku NC, Jackie OK. Phytopharmacological analysis of chemical constituents of infused Vernonia adoensis roots. Int J Pharmacol Toxicol 2014; 4(1): 28-33.

[49] Radol $\mathrm{AO}$, et al. Cytotoxicity and anti-herpes activity of selected medicinal plants cited for management of HIV conditions in Kakamega county, Kenya. British J Pharmaceut Res 2016; 13(5): 1-13.

https://doi.org/10.9734/BJPR/2016/29317

[50] Kankara SS, et al. Ethnobotanical survey of medicinal plants used for traditional maternal healthcare in Katsina state, Nigeria. S Afr J Bot 2015; 97: 165-75.

https://doi.org/10.1016/j.sajb.2015.01.007
[51] Gebeyehu G, et al. Ethnobotanical study of traditional medicinal plants and their conservation status in Mecha Wereda, West Gojjan zone of Ethiopia. Int J Pharmaceut Health Care Res 2014; 2(3): 137-54.

[52] Gelfand $M$, et al. The traditional medical practitioner in Zimbabwe: His principles of practice and pharmacopoeia. Gweru: Mambo Press; 1985.

[53] Fowler DG. Traditional fever remedies: A list of Zambian plants. Richmond: Royal Botanic Gardens, Kew; 2006.

[54] Stangeland $\mathrm{T}$, et al. Antioxidant and anti-plasmodial activity of extracts from three Ugandan medicinal plants. J Med PI Res 2010; 4: 1916-23.

[55] Nethengwe MF, et al. Larvicidal, antipyretic and antiplasmodial activity of some Zulu medicinal plants. J Med PI Res 2012; 6(7): 1255-62.

https://doi.org/10.5897/JMPR11.1319

[56] Ngarivhume $\mathrm{T}$, et al. Medicinal plants used by traditional healers for the treatment of malaria in the Chipinge district in Zimbabwe. J Ethnopharmacol 2015; 159: 224-37. https://doi.org/10.1016/j.jep.2014.11.011

[57] Sobrinho ACN, de Souza EB, Fontenelle ROS. A review on antimicrobial potential of species of the genus Vernonia (Asteraceae). J Med PI Res 2015; 9(31): 838-50.

https://doi.org/10.5897/JMPR2015.5868

[58] Kisangau DP, et al. In vitro antimicrobial assay of plants used in traditional medicine in Bukoba rural District Tanzania. Afr J Trad Compl Alt Med 2007; 4: 510-23. https://doi.org/10.4314/ajtcam.v4i4.31245

[59] Kisangau DP, et al. Use of traditional medicines in the management of HIVIAIDS opportunistic infections in Tanzania: a case in the Bukoba rural district. J Ethnobiol Ethnomed 2007; 3: 29.

https://doi.org/10.1186/1746-4269-3-29

[60] Chimponda T, Mukanganyama S. Antimycobacterial activities of selected medicinal plants from Zimbabwe against Mycobacterium aurum and Corynebacterium glutamicum. Trop Biomed 2010; 27: 595-610.

[61] Chitemerere TA, Mukanganyama S. In vitro antibacterial activity of selected medicinal plants from Zimbabwe. Afr J PI Sci Biotechnol 2011; 5(1): 1-7.

[62] Kisangau DP, et al. Traditional knowledge, use practices and conservation of medicinal plants for HIVIAIDS care in rural Tanzania. Ethnobot Res Appl 2011; 9: 43-57. https://doi.org/10.17348/era.9.0.43-57

[63] Gurib-Fakim A. Novel plant bioresources: Applications in food, medicine and cosmetics. Chichester: John Wiley \& Sons Ltd; 2014.

https://doi.org/10.1002/9781118460566

[64] Mautsa R, Mukanganyama S. Vernonia adoensis leaf extracts cause cellular membrane disruption and nucleic acid leakage in Mycobacterium smegmatis. J Biologically Active Prod Nat 2017; 7(2): 140-56.

https://doi.org/10.1080/22311866.2017.1324321

[65] Kokwaro JO. Medicinal plants of east Africa. Nairobi: Nairobi University Press; 2009.

[66] Lamorde $M$, et al. Medicinal plants used by traditional medicine practitioners for the treatment of HIVIAIDS and related conditions in Uganda. J Ethnopharmacol 2010; 130: 43-53. https://doi.org/10.1016/j.jep.2010.04.004

[67] Swamy TA, Jackie OK, Mutuku NC. Phytochemical analysis of Vernonia adoensis leaves and roots used as a traditional medicinal plant in Kenya. Int J Pharm Biol Sci 2013; 3(3): 4652.

[68] Mabona U, Van Vuuren SF. Southern African medicinal plants used to treat skin diseases. S Afr J Bot 2013; 87: 17593.

https://doi.org/10.1016/j.sajb.2013.04.002 
[69] Ragunathan M, Solomon M. The study of spiritual remedies in orthodox rural churches and traditional medicinal practice in Gondar Zuria district, northwestern Ethiopia. Pharmacog J 2009; 1: 178-83.

[70] Worku AM. A review on significant of traditional medicinal plants for human use in case of Ethiopia. Plant Pathol Microbiol 2019; 10: 484.

[71] Maiga A, et al. A survey of toxic plants on the market in the district of Bamako, Mali: traditional knowledge compared with a literature search of modern pharmacology and toxicology. J Ethnopharmacol 2005; 96: 183-93. https://doi.org/10.1016/j.jep.2004.09.005

[72] Diallo D, et al. Wound healing plants in Mali, the Bamako region: An ethnobotanical survey and complement fixation of water extracts from selected plants. Pharmaceut Biol 2002; 40: 117-28.

https://doi.org/10.1076/phbi.40.2.117.5846

[73] Nalule AS, et al. Ethnopharmacological practices in management of livestock helminthes by pastoral communities in the drylands of Uganda. Livestock Res Rural Develop 2011; 23: 2.

[74] Bohlmann F, et al. Further glaucolides from South African Vernonia species. Phytochemistry 1984; 23: 1795-8. https://doi.org/10.1016/S0031-9422(00)83497-4

[75] Muhindi SW, Ngule CM, Ramesh F. Phytochemical and antibacterial potential of Vernonia adoensis stem bark to curb cariogenic microorganisms. American J Phytomed Clinical Therapeut 2016; 4(1): 19-27.

Received on 26-07-2020

Published on 15-10-2020

\section{DOI: https://doi.org/10.29169/1927-5951.2020.10.05.8}

(C) 2020 Alfred Maroyi; Licensee SET Publisher.

This is an open access article licensed under the terms of the Creative Commons Attribution Non-Commercial License (http://creativecommons.org/licenses/by-nc/3.0/) which permits unrestricted, non-commercial use, distribution and reproduction in any medium, provided the work is properly cited. 